\title{
MADRASAH
}

Jurnal Pendidikan dan Pembelajaran Dasar

p ISSN: 1979-5599 | e ISSN: 2502-194X | Sinta 3

P a g e

\section{PENERAPAN METODE PERMAINAN BINGO UNTUK MENINGKATKAN MINAT DAN PRESTASI BELAJAR SISWA DALAM PEMBELAJARAN TEMATIK}

\author{
Khikmatul Masrohah', Cicih Wiarsih², Dedy Irawan ${ }^{3}$ \\ Universitas Muhammadiyah Purwokerto, Indonesia \\ 1khikmatul.masrohah12@gmail.com, 2cicihwiarsih.umpwt@gmail.com, 3dedyirawan@ump.ac.id
}

DOI: $10.18860 /$ madrasah.v11i2.7113

Abstrak. Tujuan dari penelitian ini untuk memperbaiki dan meningkatkan minat dan prestasi belajar peserta didik di Kelas IV SDN 2 Dukuhwaluh. Upaya tersebut dilakukan dengan menerapkan metode permainan bingo yang diharapkan dapat meningkatkan minat dan prestasi belajar peserta didik dalam pembelajaran tematik tema 7 (indahnya keragaman di negeriku) pada subtema 2 dan subtema 3. Penerapan metode permainan tersebut juga diharapkan dapat melatih kreativitas dan inovasi guru dalam mengelola pembelajaran tematik agar lebih baik lagi. Penelitian ini menggunakan metode Penelitian Tindakan Kelas (PTK) yang dilaksanakan dalam 2 siklus dan setiap siklus terdiri dari 2 pertemuan. Prosedur penelitian ini mengacu pada model Kemmis dan Mc Taggart yang meliputi perencanaan, tindakan, observasi, dan refleksi. Alat pengumpulan data dalam penelitian ini menggunakan soal tes tertulis untuk mengukur prestasi belajar peserta didik, lembar observasi aktivitas guru dan peserta didik, dan lembar angket minat belajar peserta didik. Berdasarkan penelitian, hasil minat belajar peserta didik pada siklus I diperoleh persentase $85,1 \%$ dan siklus II meningkat 3,29\% dengan persentase $88,39 \%$. Hasil prestasi belajar peserta didik siklus I memperoleh persentase $40,4 \%$ dan siklus II meningkat 36,2\% dengan persentase 76,6\%. Berdasarkan hasil penelitian dapat disimpulkan bahwa penerapan metode permainan bingo dapat meningkatkan minat dan prestasi belajar peserta didik dalam pembelajaran tematik tema 7 pada subtema 2 dan subtema 3 di kelas IV SDN 2 Dukuhwaluh.

Kata Kunci. Metode Permainan Bingo; Minat Belajar; Prestasi Belajar; Pembelajaran Tematik

Abstract. The purpose of this study to improve and increase of interest and learning achievement students in grade four of Elementary School 2 of Dukuhwaluh. These efforts are carried out by applying the method of bingo games which are expected to increase the interest and learning acvievement of students in thematic learning of theme 7 (the beauty of diversity in my country) on sub-themes 2 and sub-themes 3. Aplication of that game method is also expected to train teacher creativity and innovation thematic learning to be even better. This study uses the Class Action Research (CAR) method which is carried out in 2 cycles and each cycle consists of 2 meetings. The procedure of this study refers to the Kemmis and Mc Taggart models which include planning, action, observation, and reflection. The data collection in this study uses written test to measure student learning achievement, observation sheets of teacher activities and student activities, and questionnaires of student learning interest. Based on research, the results of student's interest learning in cycle I obtained percentage $85.1 \%$ and cycle II increased $3.29 \%$ with percentage $88.39 \%$. The results of the learning achievement of students in cycle I obtained percentage $40.4 \%$ and cycle II increased $36.2 \%$ with percentage $76.6 \%$. Based on the results of the study it can be concluded that the application of bingo game method can increase the interest and learning achievement in thematic learning of theme 7 of sub-themes 2 and sub-themes 3 in fourth grade students of Elementary School 2 of Dukuhwaluh.

Keywords. Bingo Game Method; Learning Interest; Learning Achievement; Thematic Learning

Received : 01 June 2019

Reviesed : 27 June 2019

Approved : 28 June 2019

Published : 30 June 2019

Copyright $\odot$ Madrasah Jurnal Pendidikan dan Pembelajaran Dasar. All Right Reserved.

Vol. 11 No. 2 Juni 2019

Madrasah homepage: http://ejournal.uin-malang.ac.id/index.php/madrasah/index 
This is an open access article under the CC BY-NC-ND license

(http://creativecommons.org/licenses/by-nc-nd/4.0/).

Correspondence Address: khikmatul.masrohah12@gmail.com

\section{A. PENDAHULUAN}

Proses pembelajaran merupakan suatu rangkaian kegiatan belajar mengajar antara pendidik dan peserta didik yang dilakukan secara interaktif, inspiratif, dan menyenangkan sehingga memberikan pengalaman yang bermakna bagi peserta didik dan dapat mengembangkan kemampuan yang dimilikinya. Hal tersebut sesuai dengan Peraturan Pemerintah No. 32 pasal 19 ayat (1) tahun 2013 tentang standar nasional pendidikan bahwa proses pembelajaran pada satuan pendidikan diselenggarakan secara interaktif, inspiratif, menyenangkan, menantang, memotivasi peserta didik untuk berpartisipasi aktif, serta memberikan ruang yang cukup bagi prakarsa, kreativitas, dan kemandirian sesuai dengan bakat, minat, dan perkembangan fisik serta psikologis peserta didik. Berdasarkan penjelasan tersebut bahwa pelaksanaan pembelajaran harus berpusat pada peserta didik, agar tercipta minat belajar yang baik sehingga memunculkan ketertarikan dan keaktifan dalam diri peserta didik selama proses pembelajaran.

Proses pembelajaran yang aktif sangatlah penting agar pengalaman belajar pokok siswa sesuai Permendikbud RI No. 81a Tahun 2013 tentang implementasi kurikulum yaitu mengamati, menanya, mengumpulkan informasi, mengasoisasi, dan mengkomunikasikan dapat tercapai. Kenyataannya dalam pembelajaran tematik terpadu yang dilaksanakan di sekolah dasar saat ini masih kesulitan dalam pelaksanaannya sebagaimana yang diharapkan dalam Kurikulum 2013. Berdasarkan hasil wawancara dengan guru kelas IV SDN 2 Dukuhwaluh bahwa guru kelas yang sudah menerapkan pembelajaran tematik terutama guru kelas IV mengalami kesulitan memahami dan mengelola pembelajaran tematik terpadu. Kesulitan tersebut yaitu, guru dalam menyampaikan dan mengelola pembelajaran kurang menguasai, salah satunya yaitu materi yang disampaikan masih sangat terlihat terpisah-pisah antara mata pelajaran yang satu dengan mata pelajaran yang lainnya sehingga menyebabkan kebingungan dalam diri peserta didik. Permasalahan tersebut berdampak pada rendahnya minat belajar peserta didik dalam proses pembelajaran sehingga pembelajaran menjadi pasif dan menyebabkan prestasi belajar peserta didik menjadi rendah, hal tersebut ditunjukan pada nilai UTS semester I tema 2 tahun ajaran 2018/2019 pada tabel A.1:

Tabel A.1 Nilai UTS Semester I pada Tema 2 di Kelas IV SD Negeri 2 Dukuhwaluh

\begin{tabular}{clcccccc}
\hline \multirow{2}{*}{$\begin{array}{c}\text { Jumlah } \\
\text { Siswa }\end{array}$} & Materi & \multirow{2}{*}{$\begin{array}{c}\text { Nilai } \\
\text { Rata-rata }\end{array}$} & KKM & & \multicolumn{2}{c}{ Tuntas } & \multicolumn{2}{c}{ Tidak Tuntas } \\
\cline { 5 - 8 } & & & & Siswah & $\begin{array}{c}\text { Persen- } \\
\text { tase }\end{array}$ & $\begin{array}{c}\text { Jumlah } \\
\text { Siswa }\end{array}$ & $\begin{array}{c}\text { Persen- } \\
\text { tase }\end{array}$ \\
\hline \multirow{3}{*}{26} & PPKn & 75 & 73 & 15 & $57,7 \%$ & 11 & $42,3 \%$ \\
\cline { 2 - 8 } & B. IND & 75,5 & 72 & 17 & $65,4 \%$ & 9 & $34,6 \%$ \\
\cline { 2 - 8 } & IPA & 71,7 & 71 & 12 & $46,2 \%$ & 14 & $53,8 \%$ \\
\cline { 2 - 8 } & IPS & 71 & 71 & 11 & $42,3 \%$ & 15 & $57,7 \%$ \\
\cline { 2 - 8 } & SBDP & 69 & 70 & 10 & $38,5 \%$ & 16 & $61,5 \%$ \\
\hline
\end{tabular}

Sumber: Data nilai UTS semester I kelas IV SDN 2 Dukuhwaluh tahun ajaran 2018/2019

Permasalahan rendahnya minat belajar peserta didik dalam proses pembelajaran juga ditemukan di kelas IV SD Negeri 2 Dukuhwaluh. Berdasarkan hasil observasi dan wawancara dengan guru kelas IV SD Negeri 2 Dukuhwaluh pada hari Kamis, 11 Oktober 2018 ditemukan kelemahan pembelajaran yaitu: kurangnya inovasi dalam menerapkan metode pembelajaran sehingga minat belajar dan ketertarikan peserta didik dalam menerima pembelajaran masih rendah yang ditandai dengan sebagian besar peserta didik kurang memperhatikan guru saat 


\section{MADRASAH}

Jurnal Pendidikan dan Pembelajaran Dasar

p ISSN: 1979-5599 | e ISSN: 2502-194X | Sinta 3

menjelaskan materi atau ribut sendiri. Kedua, rendahnya keaktifan dari sebagian besar peserta didik yang dalam pembelajaran tidak berani bertanya atau mengungkapkan pendapatnya pada materi yang belum dipahami serta guru cenderung mengajar masih menggunakan pendekatan yang berpusat kepada guru sehingga kurang memberi kesempatan kepada peserta didik untuk berpendapat. Ketiga yaitu, kurangnya inovasi dalam pengelolaan kelas dan guru masih kesulitan dalam menyampaikan pembelajaran tematik yang kompleks dimana materi pembelajaran melebur atau berkesinambungan tetapi, saat evaluasi atau tes yaitu mata pelajaran terpisah sehingga peserta didik mengalami kebingungan dan menjadi lamban dalam menerima materi yang berdampak pada pemahaman dan prestasi peserta didik dalam subtema pembelajaran menjadi rendah. Selain itu, guru dituntut untuk menyelesaikan materi pembelajaran pada hari itu juga dan tidak dapat diulang sehingga menyebabkan guru mengalami kesulitan dalam menyesuaikan alokasi waktu dengan materi pembelajaran.

Berdasarkan permasalahan pembelajaran di kelas IV SDN 2 Dukuhwaluh dan sesuai hasil wawancara dengan guru wali kelas IV bahwa siswa yang memiliki minat belajar tinggi cenderung aktif dan prestasi belajarnya pun lebih tinggi daripada siswa yang memiliki minat belajar rendah yang cenderung pendiam atau pasif selama proses pembelajaran. Rendahnya prestasi peserta didik di kelas IV SD Negeri 2 Dukuhwaluh dipengaruhi oleh beberapa faktor yaitu, dapat dilihat dari minat belajar peserta didik yang masih rendah dan cara guru melakukan evaluasi saat pembelajaran. Evaluasi yang dilakukan oleh guru selama ini yaitu menekankan pada penugasan yang bersifat individu dan kurangnya diskusi kelompok sehingga siswa yang bisa semakin bisa dan siswa yang belum bisa semakin tidak bisa. Hal itu berdampak pada prestasi belajar peserta didik yang menurun, maka guru diharapkan mampu mengelola pembelajaran yang menarik agar minat belajar peserta didik tinggi dan pembelajaran dapat berhasil serta bermakna. Permasalahan tersebut dapat dicari solusi yang tepat, salah satunya dengan menerapkan metode permainan.

Belajar yang dikemas dengan permainan akan menimbulkan rasa senang dan tidak terbebani sehingga memotivasi peserta didik dalam mengikuti pembelajaran. Susanto (2013:88) menjelaskan bahwa belajar dengan suasana permainan merupakan kegiatan yang dapat menimbulkan suasana menyenangkan bagi siswa dalam belajar, dan pengetahuan, keterampilan, sikap serta daya fantasi anak berkembang. Berdasarkan penjelasan tersebut bahwa belajar dengan melakukan permainan akan menimbulkan kesenangan dan interaksi yang baik antara guru dengan peserta didik maupun antar peserta didik sehingga menciptakan minat belajar yang tinggi selama proses pembelajaran. Hal itu sejalan dengan pendapat Hakim, Fahrial, \& Dona (2018:75) yang menjelaskan bahwa penggunaan metode permainan dalam pembelajaran dapat meningkatkan keaktifan dan sikap siswa lebih disiplin, tertib, serta lebih memperhatikan saat guru menjelaskan. Sesuai pendapat tersebut dapat disimpulkan bahwa penerapan metode permainan dalam pembelajaran dapat memberikan daya tarik kepada peserta didik untuk mengikuti pembelajaran, sehingga peserta didik merasa senang dan konsentrasi selama proses pembelajaran.

Salah satu permainan dalam pembelajaran yaitu permainan bingo. Silberman (2017:126) menjelaskan bahwa bingo adalah permainan berupa kartu dan tabel bernomor, jika siswa mengumpulkan tiga titik vertikal, horizontal, atau diagonal secara berturut-turut dalam menjawab soal dengan benar maka mereka berteriak "Bingo!" dan berhak mendapatkan poin karena dapat berhasil menjawab pertanyaan dengan benar, pertanyaan yang dibuat guru disesuaikan kebutuhan dan materi pembelajaran. Permainan bingo ini memunculkan kompetisi antar kelompok dan akan berpengaruh terhadap minat belajar peserta didik yang akan menimbulkan keaktifan dan semangat dalam mengikuti pembelajaran. Hapsari \& Vicky (2018:10) menjelaskan bahwa penggunaan metode permainan bingo dapat berpengaruh terhadap meningkatnya motivasi dan pemahaman siswa terhadap materi yang sedang 
diajarkan. Sesuai penjelasan tersebut bahwa minat belajar dan motivasi dalam diri perserta didik akan meningkatkan pemahaman serta prestasi belajar, sehingga peneliti memilih permainan bingo ini untuk diterapkan dalam penelitian.

Berdasarkan permasalahan yang telah dijelaskan bahwa minat dan prestasi belajar peserta didik masih rendah khususnya di kelas IV SD Negeri 2 Dukuhwaluh, maka dari itu dilalukan upaya peningkatan kualitas pembelajaran untuk meningkatkan minat dan prestasi belajar peserta didik. Peneliti berkolaborasi dengan guru sepakat untuk melakukan upaya perbaikan pembelajaran dengan melaksanakan penelitian yang berjudul Penerapan Metode Permainan Bingo untuk Meningkatkan Minat dan Prestasi Siswa Kelas IV SD Negeri 2 Dukuhwaluh. Hasil penelitian ini diharapkan memberikan manfaat bagi guru dalam melaksanakan proses pembelajaran di dalam kelas dengan menerapkan metode permainan bingo untuk meningkatkan minat dan prestasi belajar peserta didik dalam pembelajaran tematik. Penerapan metode permainan tersebut dapat melatih kreativitas dan inovasi guru untuk mengelola kelas dalam proses pembelajaran.

\section{B. METODE PENELITIAN}

Metode penelitian yang dilaksanakan adalah Penelitian Tindakan Kelas (PTK) menggunakan model Kemmis dan Mc Taggart (1982: 8) yang dijelaskan bahwa penelitian minimal terdiri dari dua siklus. Setiap Siklus terdiri dari dua kali pertemuan dan setiap pertemuan dilakukan perencanaan, pelaksanaan, observasi dan refleksi. Penelitian ini dilaksanakan di kelas IV SD Negeri 2 Dukuhwaluh pada semester II tahun ajaran 2018/2019. Penelitian tersebut dilaksanakan pada tema 7 (Indahnya Keragaman di Negeriku), siklus I dilaksanakan pada sub tema 2 (Indahnya Keragaman Budaya Negeriku) dan siklus II dilaksanakan pada subtema 3 (Indahnya Persatuan dan Kesatuan Negeriku). Subyek dari penelitian tindakan kelas ini adalah peserta didik kelas IV. Jumlah Peserta didik kelas IV adalah 26, terdiri dari 14 peserta didik laki-laki, dan 12 peserta didik perempuan.

Teknik pengumpulan data dalam penelitian ini menggunakan teknik tes dan teknik non-tes. Teknik tes berupa soal tes uraian dan teknik non-tes berupa observasi, angket, dan dokumentasi. Alat pengumpulan data dalam penelitian ini menggunakan soal tes uraian dalam lembar evaluasi peserta didik yang dibuat sesuai indikator materi pembelajaran, lembar angket minat belajar peserta didik yang dibuat sesuai indikator minat belajar, lembar observasi aktivitas guru dan lembar observasi akativitas peserta didik yang dibuat sesuai Rencana Pelaksanaan Pembelajaran (RPP) serta dokumentasi. Indikator keberhasilan dalam Penelitian Tindakan Kelas ini yaitu: 1) Adanya peningkatan minat belajar peserta didik setiap siklus dengan menerapkan metode permainan bingo sekurang-kurangnya $70 \%$ jumlah peserta didik mencapai dengan kriteria baik; 2) Adanya peningkatan prestasi belajar peserta didik dengan menerapkan metode permainan bingo pada tema 7 "Indahnya Keragaman di Negeriku" pada subtema 2 (Indahnya Keragaman Budaya Negeriku) dan subtema 3 (Indahnya Persatuan dan Kesatuan Negeriku), yaitu sekurang-kurangnya 70\% lulus mencapai KKM 72.

\section{HASIL DAN PEMBAHASAN}

\section{Hasil Penelitian}

Penelitian ini memperoleh hasil bahwa terdapat peningkatan minat dan prestasi belajar peserta didik melalui penerapan metode permainan bingo dalam pembelajaran tematik pada tema 7 di kelas IV SDN 2 Dukuhwaluh. Hal tersebut dibuktikan dengan hasil minat belajar peserta didik yang meningkat dan meningkatnya hasil tes prestasi belajar peserta didik pada setiap siklus. Minat belajar peserta didik diukur dengan cara membagikan lembar angket setelah dilaksanakannya evaluasi pembelajaran. Hasil dari minat belajar mengalami peningkatan pada setiap siklus. Pernyataan-pernyataan yang terdapat di dalam angket dibuat berdasarkan indikator minat belajar. Peningkatan hasil minat belajar peserta didik dapat dilihat pada tabel C.1 di bawah ini: 


\section{MADRASAH}

Jurnal Pendidikan dan Pembelajaran Dasar

p ISSN: 1979-5599 | e ISSN: 2502-194X | Sinta 3

Tabel C.1 Peningkatan Minat Belajar Peserta Didik

\begin{tabular}{ccccc}
\hline No & Siklus & Rata-Rata & Persentase & Kriteria \\
\hline 1 & Siklus I & 47,64 & $85,1 \%$ & Sangat Baik \\
\hline 2 & Siklus II & 49,5 & $88,39 \%$ & Sangat Baik \\
\hline
\end{tabular}

Tabel C.1 menunjukkan hasil yang diperoleh selama 2 siklus dalam 4 kali pertemuan bahwa minat belajar peserta didik dari siklus I ke siklus II mengalami peningkatan. Rata-rata nilai pada siklus I yaitu 47,64 dan persentase $85,1 \%$ dengan kriteria sangat baik. Siklus II meningkat sebesar 3,29\% dengan perolehan nilai rata-rata 49,5 dan persentase $88,39 \%$ dengan kriteria sangat baik. Hasil minat belajar peserta didik pada siklus I sudah sangat baik namun, belum sesuai dengan hasil observasi aktivitas peserta didik dan untuk mengetahui peningkatan pada siklus II maka penelitian tetap dilanjutkan. Selain itu, nilai tes prestasi belajar peserta didik belum mencapai indikator keberhasilan, maka penelitian ini dilanjutkan pada siklus II untuk memperoleh hasil minimal $70 \%$.

Hasil minat belajar peserta didik pada siklus I sudah sangat baik namun masih ada peserta didik yang menjawab pernyataan negatif dengan jawaban sangat setuju dan belum sesuai dengan hasil observasi aktivitas peserta didik, karena masih terdapat peserta didik lakilaki yang senang bergurau ketika guru sedang menjelaskan sehingga memicu keramaian di dalam kelas. Hal tersebut menandakan bahwa masih ada peserta didik yang kurang berminat dalam salah satu kegiatan pembelajaran tetapi, peserta didik mengisi lembar angket dengan jawaban yang bagus. Selain itu, peserta didik tenang dan sangat antusias ketika dilaksanakannya permainan bingo tetapi, saat guru menjelaskan suasana kelas mulai kurang kondusif lagi.

Pada siklus II dilakukan perbaikan sesuai hasil refleksi, dan perbaikan tersebut membuat proses pembelajaran menjadi lebih baik lagi. Hasil minat belajar pada siklus II ini sudah mencapai kriteria sangat baik dan mendapatkan hasil yang lebih baik dari siklus sebelumnya. Peserta didik yang bergurau atau mainan sendiri mulai berkurang dan mulai memperhatikan dengan tenang ketika guru menjelaskan materi, tidak hanya tenang saat melakukan permainan bingo saja. Berdasarkan penjelasan tersebut bahwa perhatian yang lebih dalam pembelajaran akan memunculkan minat belajar peserta didik dan memiliki pengaruh untuk memahami materi pembelajaran yang akan berdampak pada hasil tes atau evaluasi.

Hasil prestasi belajar peserta didik diukur dengan cara peserta didik diberi soal evaluasi tertulis berbentuk uraian pada setiap akhir pembelajaran. Soal tes evaluasi tersebut dibuat berdasarkan indikator pembelajaran. Prestasi belajar peserta didik selama 2 siklus mengalami peningkatan. Peningkatan tersebut dapat dilihat pada tabel C.2 di bawah ini:

Tabel C.2 Peningkatan Prestasi Belajar Peserta Didik

\begin{tabular}{clcc}
\hline No & \multicolumn{1}{c}{ Keterangan } & Siklus I & Siklus II \\
\hline 1 & Nilai Tertinggi & 96,1 & 100 \\
\hline 2 & Nilai Terendah & 10 & 31,7 \\
\hline 3 & KKM & 72 & 72 \\
\hline 4 & Jumlah Tuntas & 13 & 20 \\
\hline 5 & Tumlah Tidak Tuntas & 13 & 5 \\
\hline 6 & Rata-Rata Nilai & 56,4 & 70,3 \\
\hline 7 & Persentase Ketuntasan Belajar & $40,4 \%$ & $76,6 \%$ \\
\hline & Kriteria & Cukup & Baik \\
\hline
\end{tabular}

Pada tabel C.2 dapat disimpulkan bahwa proses pembelajaran yang dilaksanakan pada siklus I memperoleh nilai rata-rata 56,4 dan persentase ketuntasan belajar sebesar $40,4 \%$ dengan 
kriteria cukup. Hasil tersebut masih perlu diperbaiki agar dapat mencapai indikator keberhasilan. Perbaikan tersebut dilaksanakan pada siklus II dan mengalami peningkatan sebesar 36,2 \% dengan hasil rata-rata 70,3 dan persentase sebesar 76,6\% mencapai kriteria baik.

Nilai tes prestasi belajar pada siklus I belum mencapai indikator keberhasilan sehingga dilanjutkan siklus II dengan perbaikan-perbaikan pembelajaran pada siklus I agar terjadi peningkatan sesuai indikator keberhasilan yang telah ditentukan. Nilai tes prestasi belajar pada siklus II sudah mengalami peningkatan dari siklus I dan sudah mencapai indikator keberhasilan prestasi belajar yaitu $70 \%$. Berdasarkan hasil tersebut bahwa prestasi belajar peserta didik telah meningkat dan mencapai indikator keberhasilan sehingga penelitian ini dihentikan pada siklus II. Prestasi belajar yang diperoleh peserta didik selama 2 siklus telah mengalami peningkatan, hal itu tidak lepas dari aktivitas guru yang meningkat pula dalam menyampaikan dan mengelola materi pembelajaran.

\section{Pembahasan}

Penelitian ini terdiri dari dua pembahasan sebagai berikut:

\section{a. Peningkatan Minat Belajar Peserta Didik}

Minat untuk belajar dalam diri peserta didik merupakan suatu hal yang penting dalam pembelajaran karena, hal tersebut akan berpengaruh terhadap pemahaman materi yang dikuasai peserta didik. Minat belajar yang dimiliki peserta didik kelas IV SDN 2 Dukuhwaluh sesuai hasil observasi yang dilakukan oleh peneliti pada kondisi awal untuk menentukan permasalahan masih tergolong kurang. Cara untuk meningkatan minat belajar peserta didik dapat dilakukan dengan memberikan ketertarikan atau rasa senang dalam pembelajaran sehingga peserta didik dapat memberikan perhatiannya selama mengikuti kegiatan belajar mengajar. Slameto (2010:180) menjelaskan bahwa ketertarikan peserta didik dalam pembelajaran dapat muncul dengan menerapkan bahan pelajaran yang menarik agar memunculkan daya tarik dalam diri peserta didik. Sesuai penjelasan tersebut bahwa ketertarikan dapat muncul dengan memberikan suatu hal yang berbeda atau yang belum pernah dilakukan peserta didik sehingga rasa penasaran dan minat belajar peserta didik dapat muncul dan meningkat.

Sesuai penjelasan yang telah diuraikan bahwa dalam penelitian ini menerapkan metode permainan bingo sebagai stimulus peserta didik agar merasa tertarik dan senang terlebih dahulu dalam mengikuti pembelajaran. Setelah peserta didik merasa tertarik dan senang dalam mengikuti pembelajaran maka minat untuk belajar peserta didik pun dapat meningkat. Hal tersebut sejalan dengan pendapat Aida \& Julianto (2017:1008) yang menjelaskan bahwa penggunaan metode permainan bingo dalam pembelajaran dapat menggugah minat siswa, memacu semangat yang tinggi dalam pembelajaran, dan menciptakan suasana belajar yang menyenangkan. Sesuai pendapat tersebut dapat disimpulkan bahwa penerapan metode permainan bingo dalam pembelajaran dapat memberikan daya tarik kepada peserta didik untuk mengikuti pembelajaran, sehingga peserta didik merasa senang dan konsentrasi selama proses pembelajaran.

Peserta didik merasa tertarik dalam melakukan permainan tersebut, karena mereka baru mengenal permainan bingo sehingga rasa penasaran dalam diri peserta didik sangat tinggi. Penggunaan metode permainan tersebut juga dapat menciptakan suasana pembelajaran yang menyenangkan sehingga dapat memotivasi peserta didik dalam mengikuti pembelajaran. Penjelasan tersebut sesuai dengan pendapat Hapsari \& Vicky (2018:10) yang menjelaskan bahwa metode permainan bingo memiliki pengaruh terhadap motivasi dan pemahaman materi. Berdasarkan penjelasan tersebut bahwa penerapan metode permainan bingo dapat memberikan perhatian yang tinggi bagi peserta didik untuk mengikuti pembelajaran dan dapat meningkatkan minat belajar peserta didik sehingga peserta didik merasa senang dan pembelajaran menjadi bermakna serta tidak mudah dilupakan.

Meningkatnya minat belajar peserta didik juga dapat dilihat dari peningkatan aktivitas belajar peserta didik. Perubahan minat dan aktivitas belajar yang terjadi dalam diri peserta 


\section{MADRASAH}

Jurnal Pendidikan dan Pembelajaran Dasar

p ISSN: 1979-5599 | e ISSN: 2502-194X | Sinta 3

didik berbanding lurus, dan perubahan tersebut mulai muncul pada siklus I pertemuan ke 2 sedangkan pada siklus II perubahan tersebut meningkat dan sudah jelas terlihat dalam diri peserta didik. Hal demikian merupakan hasil upaya tim peneliti \& guru dengan menerapkan metode permainan bingo selama proses pembelajaran untuk meningkatkan minat belajar peserta didik. Minat belajar peserta didik dapat dilihat dari perubahan sikap yang ditunjukkannya, sesuai pendapat Slameto (2010: 180) yang menjelaskan bahwa minat belajar siswa dapat dilihat melalui: peserta didik memberikan perhatian yang besar terhadap suatu hal atau kegiatan tertentu, memiliki perasaan senang selama memperhatikan suatu hal atau kegiatan tertentu, memiliki rasa suka dan rasa ketertarikan pada suatu hal atau aktivitas, dan berpartisipasi aktif dalam suatu aktivitas. Berdasarkan penjelasan tersebut dapat disimpulkan bahwa ciri-ciri peserta didik yang memiliki minat belajar tinggi yaitu sebagai berikut:

1) Memberikan perhatian yang besar terhadap suatu hal atau kegiatan tertentu, artinya peserta didik mampu mengikuti proses pembelajaran dari awal sampai akhir dengan sungguhsungguh atau konsentrasi.

2) Perasaan senang selama memperhatikan suatu hal atau kegiatan tertentu, artinya peserta didik dalam memperhatikan atau mengikuti serangkaian pembelajaran yang dilakukan oleh guru diikuti dengan perasaan senang sehingga peserta didik menikmati dan tidak mudah bosan dalam proses peambelajaran.

3) Memiliki rasa suka dan rasa ketertarikan pada suatu hal atau aktivitas, artinya peserta didik belajar dengan kemauan sendiri dan tidak ada paksaan atau suruhan dari orang lain. Selain itu, ketertarikan peserta didik dalam pembelajaran dapat muncul dengan menerapkan bahan pelajaran yang menarik agar memunculkan daya tarik dalam diri peserta didik.

4) Berpartisipasi aktif dalam suatu aktivitas, artinya peserta didik terlibat dalam menyelesaikan persoalan selama proses pembelajaran, bertanya kepada siswa lain atau kepada guru apabila belum memahami persoalan yang dihadapinya, dan peserta didik mampu berdiskusi serta bekerjasama dengan baik bersama teman satu kelompok.

Pembelajaran yang telah dilaksanakan pada siklus I dan siklus II terdapat perubahan aktivitas peserta didik lebih baik. Salah satunya yaitu bertambahnya pengetahuan bagi peserta didik, contohnya peserta didik banyak memperoleh keterampilan seperti keterampilan berbicara didepan umum, berlatih cepat dan tepat dalam menjawab pertanyaan, berlatih mengatur waktu, dan bekerjasama dengan baik. Selain itu, peserta didik semakin aktif dalam pembelajaran dengan menggunakan permainan bingo sehingga peserta didik selalu senang dan termotivasi mengikuti pembelajaran dari awal sampai akhir. Hal itu sejalan dengan penjelasan Susanto (2013: 88) bahwa belajar dengan melakukan permainan merupakan kegiatan yang dapat menimbulkan suasana menyenangkan bagi siswa dalam belajar, dan pengetahuan, keterampilan, sikap serta daya fantasi anak akan berkembang. Berdasarkan penjelasan tersebut bahwa metode permainan adalah cara yang digunakan untuk mencapai tujuan pembelajaran dengan memasukkan unsur permainan dalam kegiatan belajar mengajar sehingga tujuan pembelajaran dapat dicapai dengan rasa senang dan gembira.

Penerapan suatu permainan dalam proses pembelajaran harus terdapat langkahlangkah penggunaannya agar teratur. Silberman (2017: 126) menjelaskan bahwa langkahlangkah yang digunakan dalam permainan bingo yaitu:

1) Lakukan penyajian materi pelajaran berbasis ceramah dengan 9 poin utama.

2) Susunlah kartu bingo yang berisi poin-poin ini dalam $3 \times 3$ tumpukan. Tempatkan satu poin yang berbeda pada tiap kotak. Jika anda memiliki kurang dari 9 poin utama, kosongkanlah beberapa kotak.

3) Buatlah beberapa kartu bingo tambahan dengan poin utama yang sama, namun tempatkan poin-poin itu dalam kotak yang berbeda. Hasilnya ialah bahwa hanya sedikit sekali kartu bingo yang serupa. 
4) Bagikan kartu bingo kepada siswa. Juga sediakan siswa dengan satu strip kartu yang terdiri dari 9 titik warna. Jelaskan kepada siswa bahwa ketika disajikan materi dari poin ke poin, mereka harus menempelkan satu titik pada kartu mereka.

5) Ketika siswa mengumpulkan tiga titik vertikal, horizontal, atau diagonal secara berturutturut, mereka akan berteriak "Bingo!".

6) Selesaikanlah penyajian materi pelajaran. Biarkan siswa mendapatkan bingo sebanyak yang mereka bisa.

Berdasarkan penjelasan dari langkah-langkah penggunaan permainan bingo tersebut, peneliti menyesuaikan metode permainan bingo dengan pembelajaran pada tema 7 melalui langkah-langkah sebagai berikut:

1) Guru menyusun soal pertanyaan sesuai dengan materi yang diajarkan.

2) Guru membagi peserta didik dalam kelompok, setiap kelompok terdiri dari 5 atau 6 orang, kemudian setiap kelompok diberi nama menggunakan nama macam-macam warna.

3) Peserta didik berkumpul bersama kelompoknya dengan cara menyanyikan lagu "Find You're Groupmates".

4) Guru membagikan kertas berbentuk bintang dengan warna sesuai nama kelompoknya dan membagikan kartu bingo yang berisi tabel bernomor berukuran $5 \times 5 \mathrm{~cm}$ sejumlah 5 kolom dan 5 baris kepada setiap kelompok.

5) Guru membacakan soal secara urut dan meminta peserta didik berdiskusi dengan kelompoknya untuk menjawab pertanyaan dengan cara menuliskan jawaban pada tempat yang telah disediakan dan diberi waktu.

6) Guru bersama peserta didik membahas soal dengan berdiskusi bersama.

7) Kelompok yang dapat menjawab dengan benar berhak menempelkan kertas bintang pada kartu bingo sesuai nomor soal yang berhasil dijawab dan mendapat poin 10.

8) Apabila suatu kelompok dapat mengisi 5 kartu bingo dengan kertas bintang secara horizontal, vertikal maupun diagonal maka kelompok tersebut meneriakkan "Bingo!" dengan cara tepuk bingo dan berhak memperoleh nilai 100.

9) Permainan dapat dilanjutkan atau dihentikan sesuai dengan kebutuhan.

Prosedur permainan bingo yang diterapkan dalam penelitian ini mempunyai beberapa atauran permainan. Aturan main tersebut antara lain:

1) Hanya kelompok yang benar dalam menjawab pertanyaan yang diperbolehkan menempelkan kertas bintang dalam kartu bingo.

2) Jika berhasil menjawab soal maka mendapatkan poin 10.

3) Jika berhasil menjawab soal yang letaknya 5 kolom atau baris secara horizontal, vertikal maupun diagonal maka seluruh anggota kelompok tersebut meneriakkan "Bingo!" dengan cara tepuk bingo dan mendapatkan poin 100.

4) Setelah semua soal terjawab dan selesai dibahas, guru menjumlah poin yang didapat masing-masing kelompok.

5) Kelompok dengan poin terbanyak menjadi pemenang.

Penerapan metode permainan bingo dalam pembelajaran, selain memiliki kelebihan juga terdapat kekurangannya. Kelebihan dan kekurangan metode permainan bingo sesuai penelitian yang telah dilaksanakan yaitu:

1) Kelebihan Metode Permainan Bingo

a) Menimbulkan antusias, artinya timbul respon yang baik terhadap suatu hal dalam kegiatan pembelajaran sehingga minat belajar peserta didik tinggi dan menimbulkan keaktifan.

b) Menimbulkan semangat, karena dilakukan dengan kompitisi sehingga kegairahan peserta didik akan menimbulkan motivasi untuk mengikuti proses pembelajaran.

c) Menimbulkan kesenangan, merupakan timbulnya pikiran tidak merasa terbebani dalam mengikuti proses pembelajaran sehingga menimbulkan keasyikan dan peserta didik menikmati pembelajaran yang sedang dilaksanakan.

2) Kelemahan Metode Permainan Bingo 


\section{MADRASAH}

Jurnal Pendidikan dan Pembelajaran Dasar

p ISSN: 1979-5599 | e ISSN: 2502-194X | Sinta 3

P a g e

a) Membutuhkan waktu yang lama, dengan melakukan permainan dalam pembelajaran maka akan banyak waktu yang tersita.

b) Sulit mengatur pembelajaran yang kondusif, karena dengan permainan peserta didik akan lebih antusias dan ramai.

\section{b. Peningkatan Prestasi Belajar Peserta Didik}

Proses pembelajaran dengan menggunakan metode permainan bingo dapat meningkatkan prestasi belajar peserta didik. Hal tersebut terbukti dengan adanya peningkatan yang terjadi pada setiap siklus, selain itu peserta didik lebih tertarik dan memiliki minat yang tinggi dalam mengikuti proses pembelajaran sehingga mampu menerima materi dengan baik dan akan berpengaruh pada hasil belajar yang didapatkan. Rosyidi (2018:93) menyatakan bahwa pembelajaran dengan metode belajar aktif menggunakan permainan bingo memiliki dampak positif dalam meningkatkan prestasi belajar siswa yang ditandai dengan peningkatan ketuntasan belajar siswa dalam setiap siklus. Berdasarkan analisis data yang diperoleh dan penjelasan tersebut bahwa penerapan metode permainan bingo dapat meningkatkan minat dan prestasi belajar peserta didik pada materi yang telah diajarkan.

Prestasi belajar yang diperoleh peserta didik selama 2 siklus telah mengalami peningkatan, hal itu tidak lepas dari aktivitas guru dalam menyampaikan materi pembelajaran. Sesuai penjelasan tersebut dapat disimpulkan bahwa terdapat beberapa faktor yang mempengaruhi prestasi belajar peserta didik. Subaryana (2015:27) menyebutkan bahwa faktorfaktor yang dapat mempengaruhi prestasi belajar peserta didik antara lain:

1) Faktor Internal. Faktor internal merupakan faktor yang berasal dari dalam diri siswa itu sendiri. Faktor ini meliputi: kemampuan siswa, motivasi belajar, minat dan perhatian, sikap dan kebiasaan belajar, sosial ekonomi, faktor fisik dan psikis.

2) Faktor Eksternal. Faktor eksternal merupakan faktor yang berasal dari luar diri siswa. Faktor ini meliputi: lingkungan keluarga, lingkungan sekolah, dan lingkungan sosial.

Berdasarkan penjelasan yang telah diuraikan bahwa faktor internal yang mempengaruhi prestasi belajar peserta didik salah satunya yaitu motivasi, minat dan perhatian peserta didik dalam mengikuti pembelajaran. Jika motivasi, minat dan perhatian peserta didik tinggi maka akan berpengaruh terhadap pemahaman materi pembelajaran yang tinggi pula dan akan berpengaruh juga terhadap prestasi belajar peserta didik. Faktor eksternal yang dapat mempengaruhi prestasi belajar peserta didik salah satunya yaitu lingkungan sekolah, contohnya yaitu pengaruh guru dalam menjelaskan materi pelajaran. Hal tersebut dapat disimpulkan jiika aktivitas guru dalam mengajar baik, maka akan berpengaruh terhadap perolehan prestasi belajar peserta didik yang baik pula.

Berdasarkan penjelasan yang telah diuraikan dijelaskan bahwa menjadi sangat penting bagi guru untuk mengetahui dan memahami prestasi belajar peserta didik baik secara individu maupun kelompok. Prestasi belajar tidak hanya sebagai indikator keberhasilan peserta didik saja, tetapi juga sebagai indikator kualitas suatu institusi pendidikan. Selain itu juga dapat dijadikan sebagai umpan balik guru dalam melaksanakan pembelajaran agar dapat melakukan perencanaan lebih baik lagi.

Penelitian Tindakan Kelas ini telah berhasil dilaksanakan, hal tersebut dapat ditunjukkan dari hasil penelitian yang telah mencapai semua indikator yang telah ditetapkan. Hasil dan pembahasan PTK ini menunjukkan bahwa melalui penerapan metode permainan bingo dapat meningkatkan minat dan prestasi belajar peserta didik dalam pembelajaran tematik pada tema 7 di kelas IV SDN 2 Dukuhwaluh.

\section{KESIMPULAN}

Berdasarkan hasil penelitian dan pembahasan dapat disimpulkan bahwa:

1. Penerapan metode permainan bingo dapat meningkatkan minat belajar peserta didik. Hal 
tersebut dapat ditunjukkan dari hasil pada siklus I diperoleh skor rata-rata 47,64 dan persentase sebesar 85,1\% dengan kriteria sangat baik. Siklus II meningkat 3,29\% dengan perolehan skor rata-rata 49,5 dan persentase sebesar $88,39 \%$ mencapai kriteria sangat baik.

2. Penerapan metode permainan bingo dapat meningkatkan prestasi belajar peserta didik. Hal tersebut dapat ditunjukkan dari pada siklus I memperoleh nilai rata-rata 56,4 dan persentase sebesar 40,4\% dengan kriteria cukup. Siklus II meningkat 36,2\% dengan nilai rata-rata 70,3 dan persentase sebesar $76,6 \%$ mencapai kriteria baik.

\section{E. SARAN}

Berdasarkan hasil Penelitian Tindakan Kelas yang telah dilaksanakan di kelas IV SD Negeri 2 Dukuhwaluh, terdapat beberapa saran yang dapat dijadikan masukan atau pertimbangan untuk melakukan penelitian selanjutnya agar lebih baik lagi. Saran tersebut antara lain:

1. Penerapan metode permainan bingo dalam pembelajaran harus disiapkan dan direncanakan dengan matang oleh guru agar pembelajaran berjalan dengan lancar sesuai langkah-langkah yang telah ditentukan sehingga tujuan pembelajaran dapat tercapai secara maksimal.

2. Guru harus lebih kreatif dan inovatif dalam mengelola pembelajaran tematik menggunakan metode permainan bingo, salah satunya dengan memberikan beberapa ice breaking agar peserta didik tidak mudah jenuh dan tetap fokus pada pembelajaran sehingga peserta didik tetap tertarik selama mengikuti pembelajaran.

3. Penggunaan metode permainan bingo dalam pembelajaran tematik dapat dikembangkan dengan menggunakan model pembelajaran yang lain yang sesuai dengan permainan bingo dalam rangka perbaikan pembelajaran agar pembelajaran tematik lebih baik lagi.

\section{REFERENSI}

Aida, M., \& Julianto. (2017). Pengaruh Media Permainan Bingo Terhadap Hasil Belajar IPA Siswa Kelas IV SDN 3 Sidokumpul Gresik. Jurnal Pendidikan Guru Sekolah Dasar, 05(03), 1000-1009. $\quad$ https://jurnalmahasiswa.unesa.ac.id/index.php/jurnal-penelitianpgsd/article/view/19965

Hakim, L., Fahrial, A., \& Dona, S. (2018). Upaya Meningkatkan Keaktifan Siswa dalam Pembelajaran Pendidikan Jasmani Menggunakan Metode Bermain untuk Siswa Kelas V SDN 2 Pagelaran Kabupaten Malang. Journal of Teaching Physical Education in Elementary School, 1(2), 65-77. http:// ejournal.upi.edu/index.php/tegar/article/view/11940

Hapsari, D., \& Vicky, D. (2018). Pengaruh Penggunaan Metode Permainan Bingo Terhadap Motivasi dan Pemahaman Materi PPKn Kelas IV SDN Sumokembangsri Sidoarjo. Jurnal Penelitian Pendidikan Guru Sekolah Dasar, 01(01), 1-11. https://jurnalmahasiswa.unesa.ac.id/index.php/jurnal-penelitianpgsd/article/view/23980

Kementerian Pendidikan dan Kebudayaan RI. (2013). Permendikbud RI No. 81a Tahun 2013 tentang Implementasi Kurikulum. Jakarta: Kemendikbud.

Kemmis, S., \& Mc. Taggart, R. (1982). The Action Research Planner. Victoria: Deakin University.

Pemerintah RI. (2013). Peraturan Pemerintah No. 32 pasal 19 ayat (1) tahun 2013 tentang Standar Nasional Pendidikan. Jakarta: Sekretariat Negara.

Rosyidi, I. (2018). Peningkatan Hasil Belajar IPA Melalui Metode Belajar Aktif Ala Permainan Bingo. Jurnal Ilmu-Ilmu Sosial dan Humaniora, 10(1), 85-94. http://ejurnal.unisda.ac.id/index.php/Humanis/article/view/334

Silberman, M. L. (2017). Active Learning 101 Cara Belajar Siswa Aktif. Bandung: Nuansa Cendekia. Slameto. (2010). Belajar \& Faktor-Faktor yang Mempengaruhinya. Jakarta: PT Renika Cipta.

Subaryana. (2015). Konsep Diri dan Prestasi Belajar. Jurnal Dinamika Pendidikan Dasar, (7)2, 2130.

Susanto, A. (2013). Teori Belajar \& Pembelajaran di Sekolah Dasar. Jakarta: Kencana. 